\title{
A histopathological and histochemical study of cholecystitis
}

\author{
Ponniah Anupama, Menon Nirmala V., Ramakrishnan Janaky, llias Laila \\ Mohammed, Mohammed Babitha Alingal, Nalakath Asiq Sideeque
}

\begin{abstract}
Aims: The present study mainly aimed to assess the qualitative and quantitative assessment of gallbladder mucins in chronic calculous cholecystitis, correlating the mucin histochemistry and morphology of the gallbladder in chronic calculus cholecystitis with each other and with chemical composition of gallstones. Methods: Hematoxylin and Eosin stained sections of the selected specimens were screened and one to two sections with adequate amount of well-preserved mucosa with lining epithelium were chosen. The corresponding paraffin blocks were selected and isolated. Four sections were cut on each of the selected blocks for special stains. Results: Comparison of inflammation and mucin histochemistry, inflammation and metaplasia, composition of calculi and grade of inflammation, composition of stones and mucin
\end{abstract}

Ponniah Anupama ${ }^{1}$, Menon Nirmala $\mathrm{V}^{2}{ }^{2}$, Ramakrishnan Janaky $^{3}$, llias Laila Mohammed ${ }^{1}$, Mohammed Babitha Alingal ${ }^{1}$, Nalakath Asiq Sideeque ${ }^{4}$

Affiliations: ${ }^{1}$ MBBS, MD, Assistant Professor, Department of Pathology, MES Medical College, Perinthalmanna, Kerala, India; ${ }^{2}$ MBBS, MD, Professor, PSG Institute of Medical Sciences and Research, Coimbatore, Tamil Nadu, India; ${ }^{3}$ MBBS, Junior Resident, Department of Pathology, MES Medical College, Perinthalmanna, Kerala, India; ${ }^{4} \mathrm{MBBS}$, MD, Professor and Head of Department, Department of Pathology, MES Medical College, Perinthalmanna, Kerala, India.

Corresponding Author: Dr. Ponniah Anupama, Department of Pathology, MES Medical College and Hospital, Malaparamba, Palachode P. O, Kolathur via, Perinthalmanna, Malapuram District, Kerala, India. Postal Code -679338; Ph: +919447973557; Email: anupamasanjaynair@gmail. com

Received: 26 September 2014

Accepted: 29 October 2014

Published: 30 December 2014 histochemistry, composition of calculi and metaplasia, fibrosis and mucin histochemistry, fibrosis and stone composition indicated a decrease in intraepithelial total acid mucin content in chronic calculous cholecystitis. Cases with severe inflammation showed the maximum decrease in sulfomucin, concomitant increase in sialomucin scores and a high incidence of gastric metaplasia. Intestinal metaplasia on other hand did not correlate with the degree of inflammation or sialomucin content. Conclusion: This study concludes that normally gallbladder epithelium contains sulfated acid mucins with traces of neutral and sialomucins. The sulfomucin content decreases in chronic calculous cholecystitis and with severe inflammation, total acid mucin content decreases, neutral mucin increases, and there is a higher incidence of gastric metaplasia and pigment stones and correlating with pigment stones. This tends to have an association with severe inflammation, higher degree of fibrosis, gastric metaplasia and presence of sialomucin.

Keywords: Chronic calculous cholecystitis, Gallbladder stones, Metaplasia, Mucin histochemistry

\section{How to cite this article}

Anupama P, Menon Nirmala V, Janaky R, Mohammed IL, Alingal MB, Sideeque NA. A histopathological and histochemical study of cholecystitis. Int $\mathrm{J}$ Hepatobiliary Pancreat Dis 2014;4:70-80.

Article ID: 100025IJHPDPA2014

$$
* * * * * * * * *
$$

doi:10.5348/ijhpd-2014-25-OA-13 


\section{INTRODUCTION}

Million people are affected by gallstones and are common major factor of morbidity throughout the world, necessitating hospitalization and cholecystectomy. Cholesterol saturated as 'lithogenic' bile originating from the liver and considered an important factor in gallstones formation has been found in healthy individuals [1]. Lithogenic bile therefore cannot be the only factor involved in the process. Other factors such as super saturation of bile with calcium [2], gallbladder mucus, prostaglandins and functional failure of electrolyte absorption by gallbladder mucosa also may influence gallstone formation. Biliary calcium can reduce the solubility of cholesterol [3] rendering the bile lithogenic. Apart from being a critical initiating factor, calcium is physicallyincorporated intogallstones as well. Gallbladder mucus has long been recognized as an important factor contributing to gallstone development $[4,5]$. The implication of mucin in gallstone formation has been widely studied. Hypersecretion of mucus occurs during gallstone formation in humans [6-9] and experimental animals [10]. Apart from forming the nucleus for calculus, the mucins form a structural component of gallstones as shown by histochemical studies on calculi $[11,12]$. Calcium and prostaglandins can stimulate mucus secretion by gallbladder mucosa [13-15]. Normal human gallbladder contains predominantly sulfated acid mucin [16]. It is this sulfated mucin content that is increased in gallstone disease. Metaplastic and neoplastic gallbladder epithelium on the other hand shows an increase in sialomucins and decrease in sulfomucins. Several studies have suggested progression from metaplasia, through dysplasia, to adenocarcinoma of gallbladder [17]. The existence of such a pathway has not been definitely proven.

\section{Mucins}

Mucins are the chemical components of the secretion delivered by certain types of epithelial and connective tissue cells. The original term mucin was coined by Carpenter as early as in the year 1846 [18]. Reid and Clamp in 1978 suggested glycoconjugates as general term, which could be subdivided into 'proteoglycans' and 'glycoproteins' [19].

Free hexose groups are often available, together with certain acidic moieties, the presence of which will markedly influence histochemical reactivity. The different mucins may be present as a single type within a given tissue unit, or more usually as a mixture of different types. The synthesis of mucin is initiated in the rough endoplasmic reticulum of the producing cells and is completed in the Golgi apparatus. Sulfation of the hexosamine molecule occurs in the Golgi region $[8,20]$.

Scheme of an easy method to classify the mucin like a proteins the only two classical techniques [8].

\begin{tabular}{lll}
\hline & AB-PAS & HID-AB \\
\hline Neutral Mucins & Red & Negative \\
Sulfomucins & Red-blue & Brown-black \\
Sialomucins & Red-blue & Blue \\
Sulfo-Sialomucins & Red-blue & Brown-blue \\
\hline
\end{tabular}

$\mathrm{AB}-\mathrm{PAS}$, sequential staining with $\mathrm{AB}$ (2.5) (blue) and PAS (red); $\mathrm{HID}-\mathrm{AB}$, sequential staining with $\mathrm{HID}$ (brown to black) and $\mathrm{AB}$ (2.5) (blue).

The different types of mucins which can be distinguished histochemically are as follows [21]:

\section{Acid Mucins}

1. Strongly sulfated
(a) connective tissue
(b) epithelial

2. Weakly sulfated

Sulfated; histochemically atypical

3. Carboxylated; sialomucin
(a) enzyme - labile ( $\mathrm{N}$-acetyl form)
(b) enzyme - Resistant (N-acetyl O-acetyl form)

4. Sulfated sialomucin

5. Carboxylated; non-sulfated uronic acid (Hyaluronic acid)

\section{Neutral Mucins}

There are no subdivisions to this group

\section{MATERIALS AND METHODS}

A total number of 40 specimens were selected from gallbladders with clinical and histopathological diagnosis of chronic calculous cholecystitis received in the department of pathology PSG Institute of Medical Sciences and Research during the period of 2005-2007. criteria for selection were:

(1) Histopathological confirmation of chronic calculous cholecystitis.

(2) Presence of calculous accompanying the specimen.

(3) Availability of sufficient mucosa and well preserved lining epithelium in sections.

(4) Availability of corresponding paraffin blocks.

While 36 specimens fulfilled the above criteria, four cases had only biliary sand in the container. Three gallbladders resected for choledochal cysts, were taken as controls. Hematoxylin and Eosin (H\&E) stained sections of the selected specimens were screened and one to two sections with adequate amount of well-preserved mucosa with lining epithelium were chosen. The corresponding paraffin blocks were selected and isolated. Four sections were cut on each of the selected blocks for special stains. A pro forma was prepared for assessment. The slides were assessed according to the pro forma. 


\section{Hematoxylin and Eosin Stain}

Sections stained with H\&E were assessed for the intensity of inflammation and degree of fibrosis, which in turn were graded as mild, moderate and severe $(1+, 2+$, $3^{+)}$(Figures 1 and 2). The number of Rokitansky Aschoff sinuses was indicated as many, few and nil. Gastric metaplasia and intestinal metaplasia were also noted and indicated as present or absent (Figures 3 and 4).

\section{Mucin Histochemistry}

The following special stains for mucin were done with a view to assess the quantity and quality of mucins in the superficial and deep parts of gallbladder mucosa.

1. High Iron Diamine - Alcian Blue Stain (HID-AB)

2. Alcian Blue - Periodic Acid Schiff (AB-PAS)

A scoring system was devised, based on the percentage positivity of cells in each field under low power examination (10X), as shown below:

$$
\begin{array}{lll}
75 \%-100 \%- & 5^{+} \\
50 \%-75 \% & - & 4^{+} \\
25 \%-50 \% & - & 3^{+} \\
5 \%-25 \% & - & 2+ \\
0 \%-5 \% & - & 1+(\text { Figures 5-8) }
\end{array}
$$

The values were tabulated and statistically assessed using ANOVA, t-test, $\mathrm{x}^{2}\left(\mathrm{Chi}^{2}\right)$ test.

Biochemical analysis of calculi, wherever available (36 samples) was performed to determine the chemical composition of calculi. Gross parameters such as external appearance, colour, number of stones and weight were noted. The following biochemical procedures were carried out on the 36 samples of calculi.

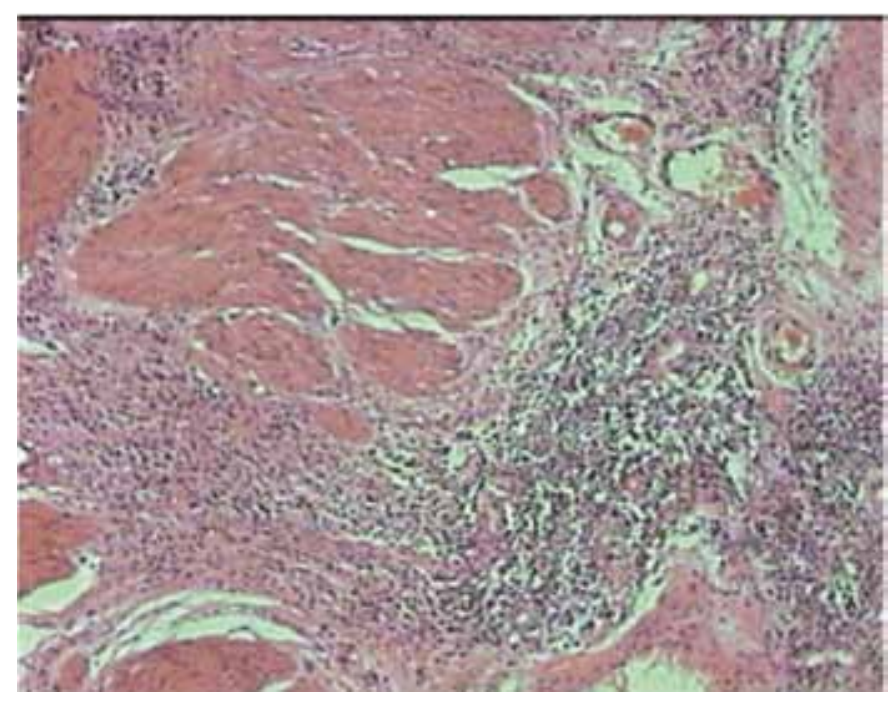

Figure 1: Severe (Grade III) inflammation of gallbladder. Dense Sheets of lymphocytes extended between smooth muscle bundles (H\&E stain, x100).

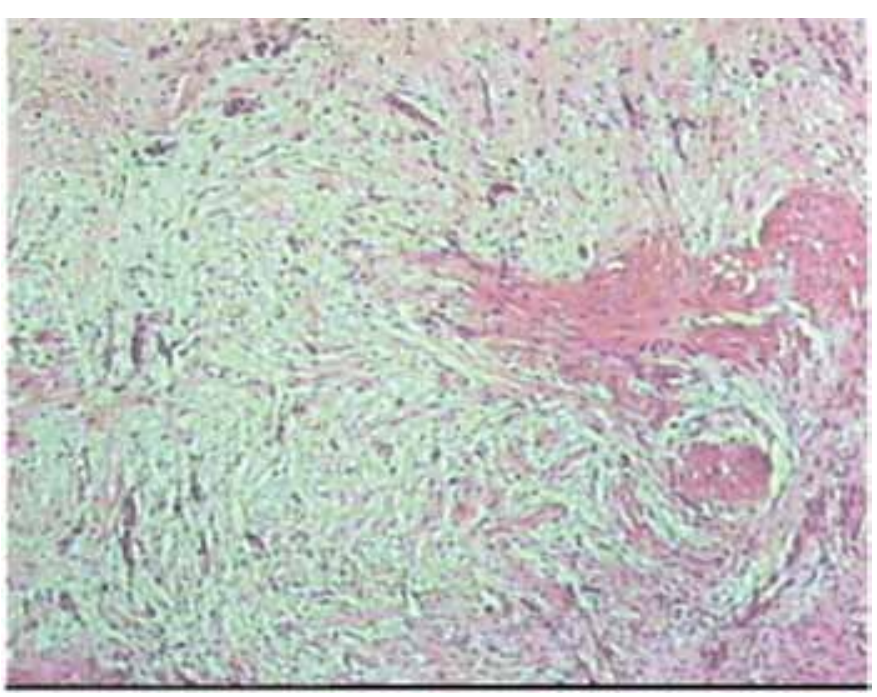

Figure 2: Severe fibrosis of gallbladder (H\&E stain, x100).

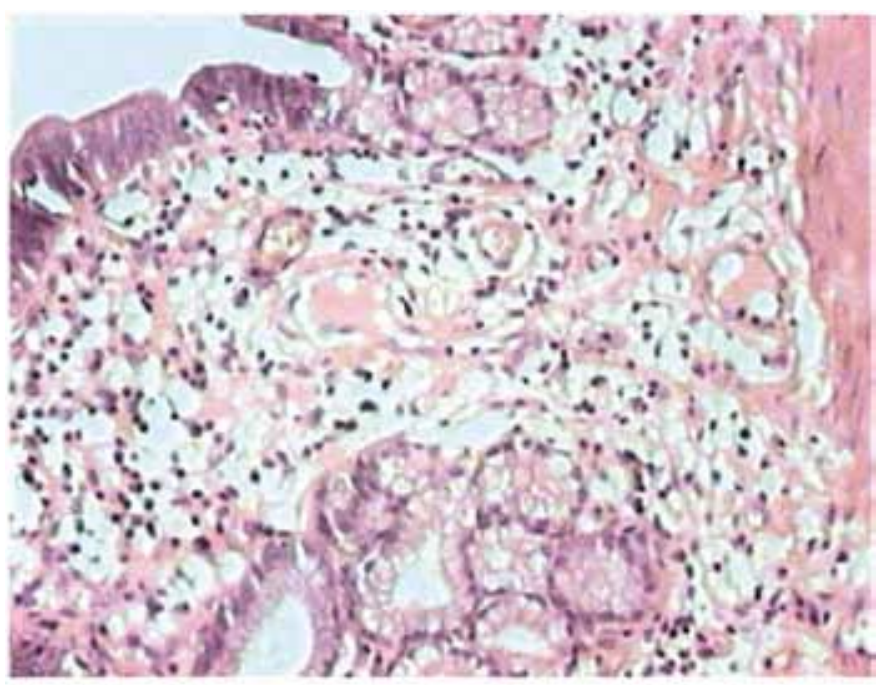

Figure 3: Photomicrograph showing Pyloric metaplasia in the deeper mucosa (H\&E stain, x100).

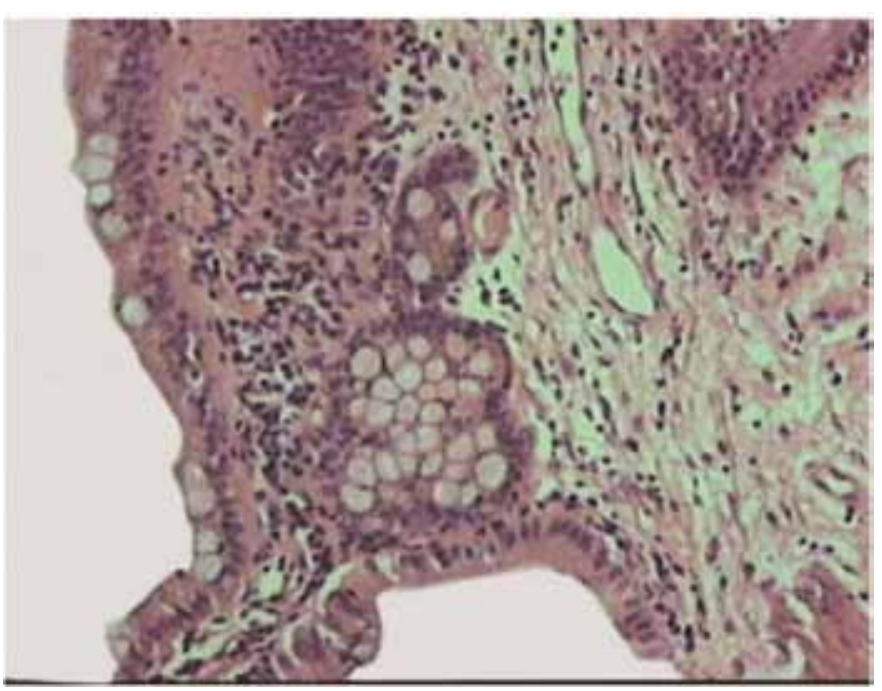

Figure 4: Intestinal metaplasia characterized by goblet cells in the gallbladder mucosa (H\&E stain, x100). 


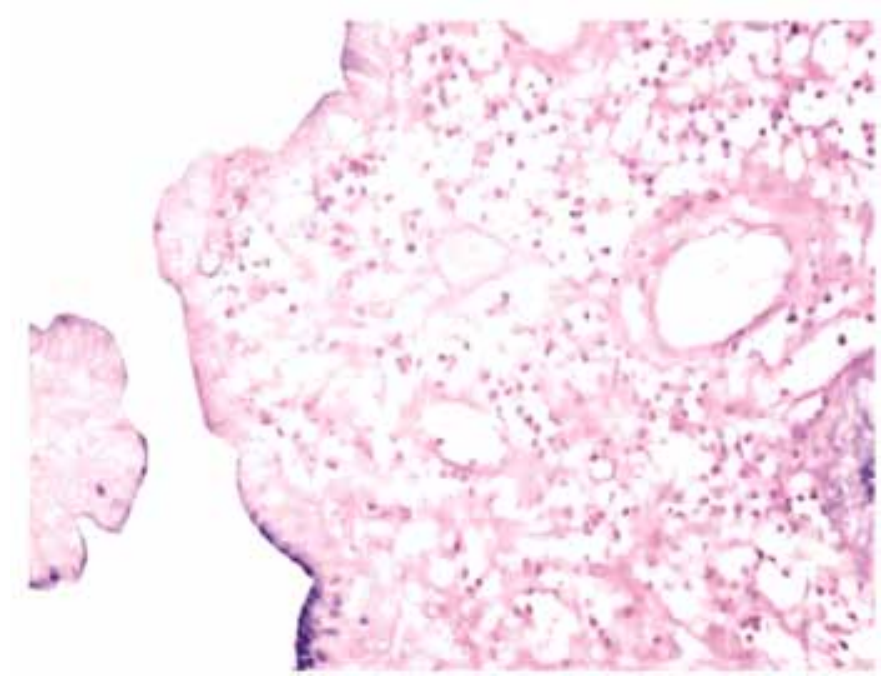

Figure 5: Score I - About 5\% of cells contain mucin (AB-PAS stain, x100).

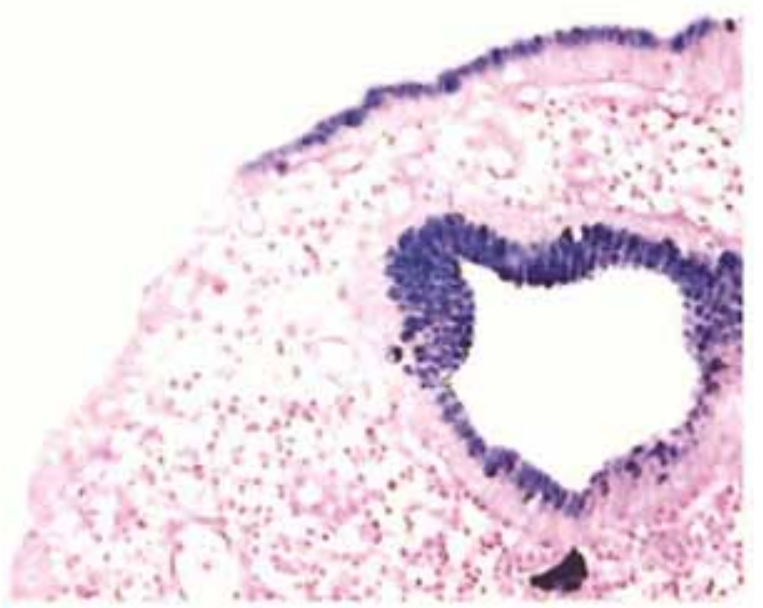

Figure 6: Score 3 - About 50\% of cells contain mucin (AB-PAS stain, x100).

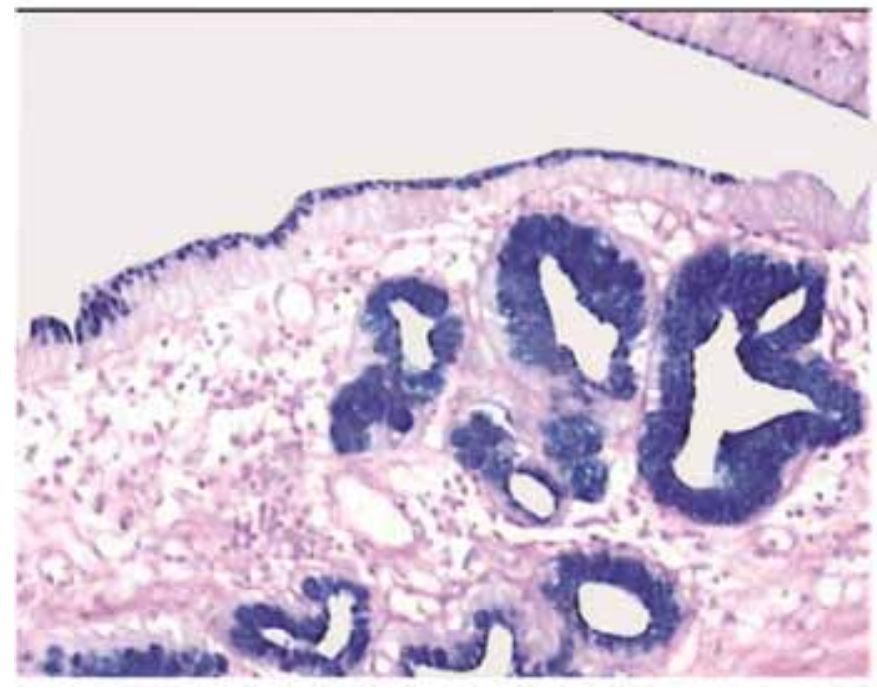

Figure 7: Score 4 - About $75 \%$ of cells contain mucin (AB-PAS stain, x100).

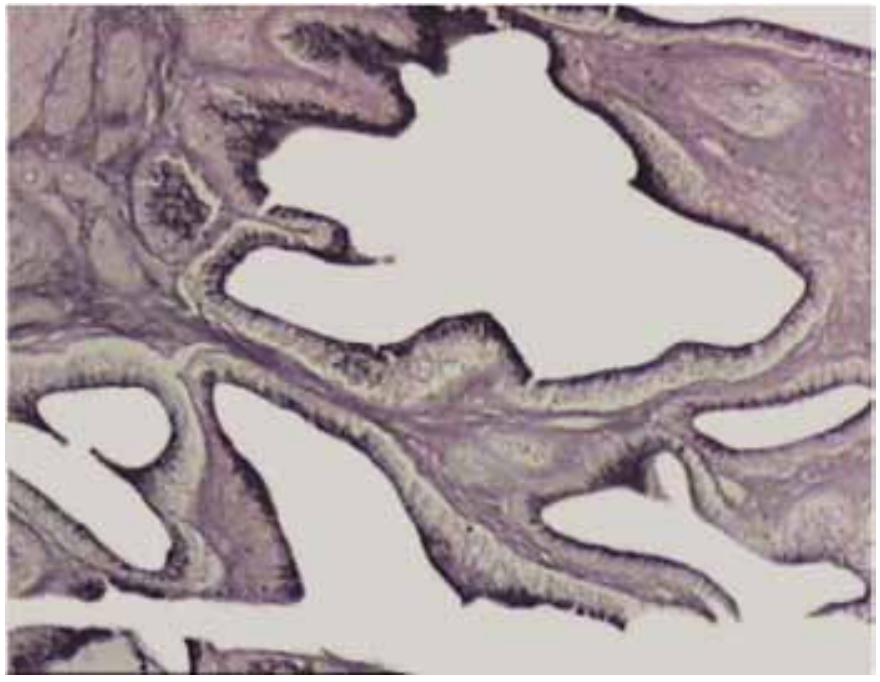

Figure 8: Score 5 - About 75-100\% of cells contain mucin (HID$\mathrm{AB}$ stain, $\mathrm{x100)}$.

\section{Biochemical analysis [22] \\ Cholesterol}

Wash the gallstones with water and dry. Powder the stone and heat some with successive small portions of ether in a test tube by inserting the tube in some warm water and filter. Dissolve a little of residue obtained on evaporation of the ether in chloroform and add a little of mixture of acetic anhydride and sulfuric acid (in the proportion of $10 \mathrm{~mL}$ to $0.1 \mathrm{~mL}$ ). A dark green colour develops rapidly.

\section{Phosphate and Calcium Oxalate}

Treat the remaining residue after ether extraction, with dilute hydrochloric acid (25\%). This dissolves the inorganic salts present. Filter and test the filtrate for phosphate with molybdate. Make some of the solution alkaline with ammonia and add acetic acid and ammonium oxalate solution. If calcium is present, a precipitate of calcium oxalate is formed.

\section{Bile Pigment}

Test the precipitate remaining after treatment with hydrochloric acid for bile pigments. Wash the material remaining on the filter paper and extract with warm chloroform. Examine the chloroform extract for bilirubin by means of diazo reagent. Change to pink color indicates presence of bile pigment. The mucin histochemistry scores obtained were tabulated, separately for the three grades of inflammation and fibrosis. An attempt was made to correlate the score with degree of inflammation, fibrosis, presence of metaplasia (intestinal and pyloric) and type of stone. Statistical assessment of the results was also performed. 


\section{RESULTS}

The three specimens of gallbladder used as a control in the present study showed predominantly Alcian blue (AB) positive mucins in the surface and deep mucosal epithelium. Periodic Acid Schiff (PAS) positivity was seen in traces. The comparison of inflammation and mucin histochemistry, inflammation and metaplasia, composition of calculi and grade of inflammation, composition of stones and mucin histochemistry, composition of calculi and metaplasia, fibrosis and mucin histochemistry, fibrosis and stone composition was done.

High iron diamine and alcian blue (HID-AB) stain was done in the three controls and it showed strong HID-AB positivity indicating the predominance of sulfomucin in superficial and deep mucosa and evaluated by mean score which is normally observed in the normal gallbladder mucosa (Table 1).

Comparison of inflammation and mucin histochemistry (Tables 2 and 3) showed that out of the total 36 cases studied, 9 (25\%) cases showed mild (Grade I) inflammation, $16(44.4 \%)$ cases showed moderate (Grade II) inflammation and 11 (30.5\%) cases showed severe (Grade III) inflammation. The mean scores for $A B$ positive (acid mucins) in the superficial and deep mucosa, in the three grades of inflammation showed a progressive decrease for Alcian Blue positive (acid) mucins in the superficial and deep mucosal epithelium, with increasing grades of inflammation (Table 2). The mean scores for PAS positive mucins in the superficial and deep mucosa were higher in Grade III inflammation, than in Grade 1 inflammation. Grade II inflammation, however, shows random scores, not conforming to any pattern (Table 2). The mean scores for HID (sulfomucin) positive are the lowest for Grade III inflammation. A progressive decrease in HID scores was observed in the superficial mucosal epithelium (Table 3). Alcian Blue (sialomucin) scores were seen to be highest in Grade III inflammation (Table 3).

Comparison of grades of inflammation and metaplasia (Table 4) showed that out of the 36 cases, 13 (36.1\%) cases showed intestinal metaplasia, 12 (33.3\%) showed gastric metaplasia and 11 (30.5\%) cases did not show any metaplasia. Metaplastic epithelium is characterized by presence of PAS positive mucins and/or goblets cells containing $\mathrm{AB}$ positive mucins in $\mathrm{AB}-\mathrm{PAS}$ stains sections (Figures 9-11). Intestinal metaplasia has the highest incidence in Grade I inflammation (56\%), and is lowest in Grade II inflammation (19\%). The reverse is seen with gastric metaplasia, which has the highest incidence in Grade III Inflammation (46\%), and a considerably lower incidence in Grade I inflammation (11\%).

Comparison of composition of calculi and grade of inflammation (Table 5), 3 cases out of 36 cases did not show calculi. 13 (39.3\%) cases showed cholesterol calculi and $20(60.6 \%)$ cases showed pigment stone calculi. The presence of pigment stones appears to correlate with severity of inflammation $[(3 / 8(37.5 \%)$ in Grade I
Table 1: HID-AB stain showed strong HID positivity indicating predominance of sulphomucins.

\begin{tabular}{|c|c|c|c|}
\hline \multirow{2}{*}{ Techniques } & & AB-PAS & HID-AB \\
\hline & & Superficial & Deep \\
\hline \multirow{2}{*}{ AB-PAS } & $\mathrm{AB}$ & $4 \cdot 7$ & 2.6 \\
\hline & PAS & 0.06 & 0.03 \\
\hline \multirow{2}{*}{ HID-AB } & HID & 4.5 & 2.8 \\
\hline & $\mathrm{AB}$ & O & 0.03 \\
\hline
\end{tabular}

HID High iron diamine, AB Alcian blue, PAS Periodic Acid Schiff

Table 2: Comparison of inflammation and mucin histochemistry- AB PAS STAIN.

\begin{tabular}{lllll}
$\begin{array}{c}\text { Inflammation } \\
\text { Grade }\end{array}$ & $\begin{array}{c}\text { Alcian blue } \\
\text { [Acid Mucin] } \\
\text { Mean Score } \\
\text { Superficial }\end{array}$ & \multicolumn{2}{c}{$\begin{array}{c}\text { Pas Deep } \\
\text { Mucin] } \\
\text { Mean Score }\end{array}$} & $\begin{array}{c}\text { Superficial } \\
\text { Deep }\end{array}$ \\
\hline I (9 cases) & 2.7 & 3.4 & 0.25 & 0.14 \\
II (16 cases) & 2.2 & 3.1 & 0.11 & 0.31 \\
III (11 cases) & 1.95 & 2.5 & 0.29 & 0.4 \\
\hline
\end{tabular}

Table 3: Comparison of inflammation and mucin histochemistry: HID-AB.

\begin{tabular}{lccccc}
\hline $\begin{array}{l}\text { Inflamm- } \\
\text { ation } \\
\text { Grade }\end{array}$ & $\begin{array}{c}\text { HID - [Sulfo- } \\
\text { mucin] } \\
\text { Mean Score } \\
\text { Superficial }\end{array}$ & $\begin{array}{c}\text { Inflam- } \\
\text { mation } \\
\text { Grade }\end{array}$ & $\begin{array}{c}\text { Alcian Blue - } \\
\text { [Sialomucin] } \\
\text { Mean Score }\end{array}$ \\
I (9 cases) & 3.9 & 3.6 & $\begin{array}{c}\text { I (9 } \\
\text { cases) } \\
\text { Superficial }\end{array}$ & Deep \\
II (16 cases) & 2.5 & 3.9 & $\begin{array}{c}\text { II (16 } \\
\text { cases) }\end{array}$ & 0.14 & 0.19 \\
III (11 cases) & 2.1 & 2.8 & $\begin{array}{c}\text { III (11 } \\
\text { cases) }\end{array}$ & 0.3 & 0.13 \\
\hline
\end{tabular}

Table 4: Comparison of grades of inflammation and metaplasia.

\begin{tabular}{|c|c|c|c|c|}
\hline \multirow[b]{2}{*}{$\begin{array}{l}\text { Type of } \\
\text { Metaplasia }\end{array}$} & \multicolumn{4}{|c|}{ Inflammation Grade } \\
\hline & $\begin{array}{c}\text { I } \\
(9 \\
\text { cases) }\end{array}$ & $\begin{array}{c}\text { II } \\
(16 \\
\text { cases) }\end{array}$ & $\begin{array}{c}\text { III } \\
\text { (11 } \\
\text { cases) }\end{array}$ & $\begin{array}{c}\text { Total } \\
\mathbf{3 6}\end{array}$ \\
\hline $\begin{array}{l}\text { Intestinal } \\
\text { metaplasia }\end{array}$ & $\begin{array}{c}5 \\
(56 \%)\end{array}$ & $\begin{array}{c}3 \\
(19 \%)\end{array}$ & $\begin{array}{c}5 \\
(22 \%)\end{array}$ & 13 \\
\hline Gastric metaplasia & $\begin{array}{c}1 \\
(11 \%)\end{array}$ & $\begin{array}{c}6 \\
(38 \%)\end{array}$ & $\begin{array}{c}5 \\
(46 \%)\end{array}$ & 12 \\
\hline
\end{tabular}

Table 5: Comparison of calculi and grade of inflammation.

\begin{tabular}{lcc}
\hline $\begin{array}{l}\text { Grade of } \\
\text { Inflammation }\end{array}$ & $\begin{array}{c}\text { Pigment } \\
\text { Stone }\end{array}$ & $\begin{array}{c}\text { Cholesterol } \\
\text { Stone }\end{array}$ \\
\hline I (8 cases) & 3 & 5 \\
II (14 cases) & 8 & 6 \\
III (11 cases) & 9 & 2 \\
TOTAL -33 & TOTAL - 20 & TOTAL - 13 \\
\hline
\end{tabular}




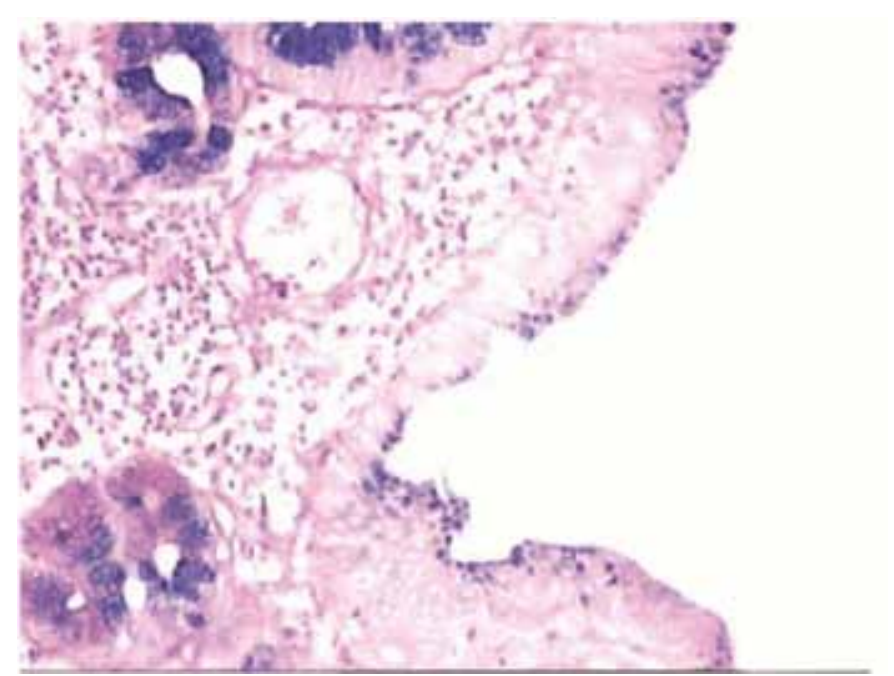

Figure 9: This field showing gastric and intestinal metaplasia. The gastric metaplastic epithelium showing PAS and Alcian blue positive mucins. Goblet cells of intestinal metaplasia are Alcian Blue positive mucins (AB-PAS stain, X100).

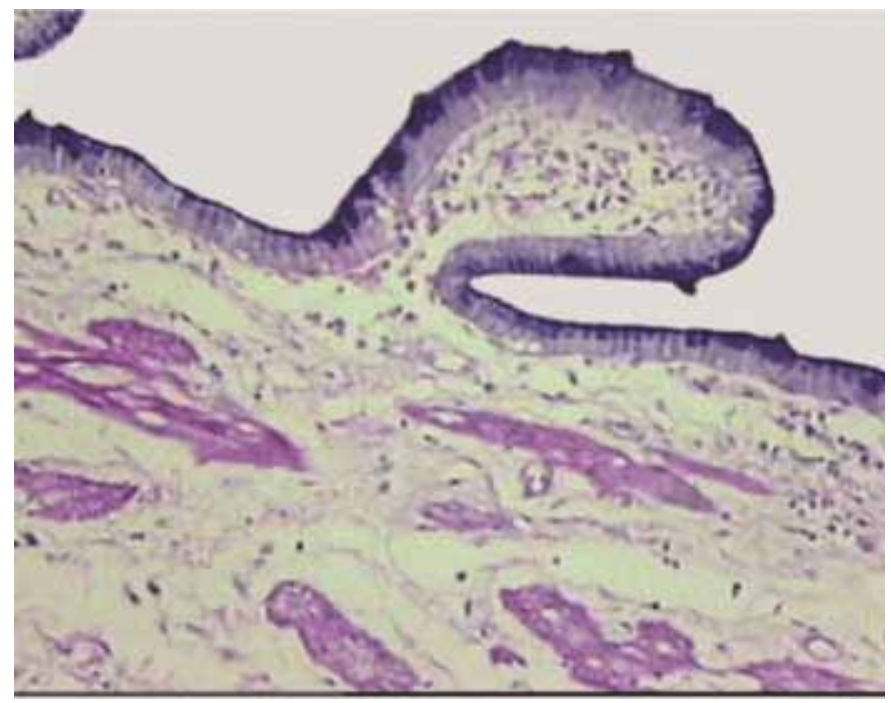

Figure 10: Intestinal metaplasia-Gallbladder goblet cells contain Alcian blue positive mucin (AB-PAS stain, x100).

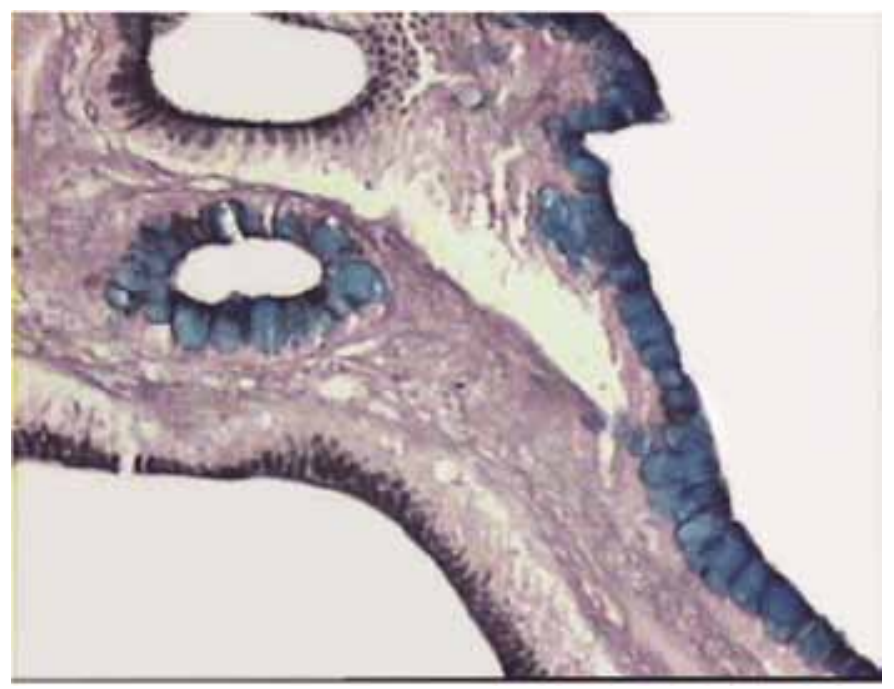

Figure 11: Gastric Metaplasia (Gall Bladder). The non neoplastic epithelium is HID positive (Brown) metaplastic epithelium Alcian blue positive (Blue) (HID-AB stain, x100). inflammation, 9/11(81.8\%) in Grade III inflammation)] as against cholesterol stones $[(5 / 8(62.5 \%)$ in Grade I inflammation, 2/11(18.1\%) in Grade III inflammation].

Comparison of stones and mucin histochemistry (Table 6) showed that the mean scores of sialomucins in the superficial and deep mucosal epithelium are higher in cases with pigment stones (0.85, 0.72),when compared with those having cholesterol stones $(0.24,0.58)$ the number of cases that show presence of sialomucins is low with both types of calculi (5/20 cases with pigment stones and 6/13 cases with cholesterol stones).

Comparison of composition of calculi and metaplasia (Table 7) showed that intestinal metaplasia is more or less equally associated with pigment and cholesterol calculi (35\% and 30\% incidence). Gastric metaplasia showed a considerably higher incidence (40\%) in association with pigment stones, when compared with cholesterol stones (23\%).

Comparison of fibrosis and mucin histochemistry (Table 8), out of 40 cases, $33(82.5 \%)$ cases showed fibrosis. Alcian blue scores (acid mucins) are slightly lower in Grade III fibrosis, compared with Grade I. Neutral mucins (PAS positive) on the other hand showed higher scores in Grade III as against Grade I fibrosis. No correlation was seen between HID scores (for sulfomucins) and degree for fibrosis. Alcian blue scores (for sialomucins) are the lowest with Grade III fibrosis (Table 8).

Comparison of fibrosis and stone composition (Table 9) showed that out of the 33 cases pigment stones had a higher incidence in Grade III fibrosis 80\% (4/5) as against Grade I fibrosis 52.6\% (10/19).

\section{DISCUSSION}

Attempts have been made in the past to correlate gallbladder morphology, mucin histochemistry, and composition of calculi in gallstone disease [16, 23, 24]. Most of the previous studies, however, have combined any two of the three aspects, that is, either morphology

Table 6: The comparison of stones and mucin histochemistry.

\begin{tabular}{lllll} 
& Pigment Stones & Cholesterol Stones \\
Total number & 20 & & 13 & \\
$\begin{array}{l}\text { Sialomucins } \\
\text { present in }\end{array}$ & 5 & & 6 & \\
$\begin{array}{l}\text { Sialomucin } \\
\text { score }\end{array}$ & Superficial & Deep & Superficial & Deep \\
& 0.85 & 0.72 & 0.24 & 0.58 \\
\hline
\end{tabular}

Table 7: Comparison of composition of calculi and metaplasia.

\begin{tabular}{lcc}
$\begin{array}{l}\text { Types of } \\
\text { Metaplasia }\end{array}$ & $\begin{array}{c}\text { Pigment } \\
\text { Stones }\end{array}$ & $\begin{array}{c}\text { Cholesterol } \\
\text { Stones }\end{array}$ \\
\hline Intestinal metaplasia & $35 \%$ & $30 \%$ \\
Gastric metaplasia & $40 \%$ & $23 \%$ \\
\hline
\end{tabular}


Table 8: Fibrosis and mucin histochemistry AB-PAS \& HID-AB stain.

\begin{tabular}{|c|c|c|c|c|c|c|c|c|}
\hline \multirow{2}{*}{$\begin{array}{l}\text { Fibrosis } \\
\text { Grade }\end{array}$} & \multicolumn{2}{|c|}{$\begin{array}{c}\text { AB[Acid } \\
\text { Mucin] } \\
\text { Mean Score }\end{array}$} & \multicolumn{2}{|c|}{$\begin{array}{c}\text { PAS } \\
\text { [Neutral } \\
\text { mucin] } \\
\text { Mean Score }\end{array}$} & \multicolumn{2}{|c|}{$\begin{array}{c}\text { HID } \\
\text { [Sulpho- } \\
\text { mucin] }\end{array}$} & \multicolumn{2}{|c|}{$\begin{array}{c}\text { AB } \\
\text { [Sialo } \\
\text { Mucin] } \\
\text { Mean } \\
\text { Score }\end{array}$} \\
\hline & 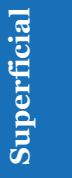 & $\begin{array}{l}\text { के } \\
\text { هั }\end{array}$ & 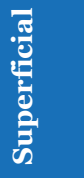 & 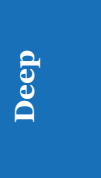 & 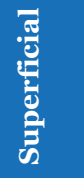 & $\begin{array}{l}\text { षิن } \\
\text { مे }\end{array}$ & 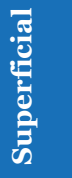 & $\begin{array}{l}\text { बिं } \\
\text { ه̆ }\end{array}$ \\
\hline $\begin{array}{l}\text { I (19 } \\
\text { cases) }\end{array}$ & 2.46 & 2.81 & 0.13 & 0.22 & 2.64 & 3.52 & 0.11 & 0.17 \\
\hline $\begin{array}{l}\text { II ( } 9 \\
\text { cases) }\end{array}$ & 3.0 & 3.1 & 0.96 & 0.45 & 3.08 & 3.27 & 0.26 & 1.97 \\
\hline $\begin{array}{l}\text { III ( } 5 \\
\text { cases) }\end{array}$ & 2.0 & 1.7 & 0.85 & 0.32 & 1.7 & 3.7 & o & 0.08 \\
\hline
\end{tabular}

Table 9: Comparison of fibrosis and stone composition.

\begin{tabular}{lcccc}
$\begin{array}{l}\text { Grade of } \\
\text { Fibrosis }\end{array}$ & $\begin{array}{c}\text { Pigment } \\
\text { Stone }\end{array}$ & $\begin{array}{c}\text { Cholesterol } \\
\text { Stone }\end{array}$ & $\begin{array}{c}\text { No } \\
\text { Stones }\end{array}$ & Total \\
\hline I & 10 & 6 & 3 & 19 \\
II & 5 & 3 & 1 & 9 \\
III & 4 & 1 & 0 & 5 \\
Total (33) & 23 & 13 & 4 & 33 \\
\hline
\end{tabular}

with mucin histochemistry, mucin histochemistry with composition of calculi or composition of calculi with morphology. Few studies correlating all three with one another have been recorded in literature. Purpose of this study was to determine whether qualitative and/ or quantitative variations in gallbladder mucins occurs in chronic calculous cholecystitis and whether the alterations, if any, correlate with morphological changes in the gallbladder and/or with the type of calculous present. In short, an attempt has been made through this study, to correlate gallbladder morphology, mucin histochemistry and composition of calculi to one another, in chronic calculous cholecystitis specimens.

Gallbladders removed for choledochal cysts were the control in the present study. The mucosal histology was normal and there was no inflammation, fibrosis or metaplasia. AB-PAS and HID-AB staining of sections showed predominantly HID positive sulfated acid mucins throughout the mucosa, with traces of sialomucins and neutral mucins in foci. Normal gallbladder mucosa is known to contain predominantly sulfomucins. Traces of sialomucins and neutral mucins also may present [24]. Our observations on control samples conform to this well established normal pattern of mucin histochemistry of gallbladder mucosa. Our results indicate a decrease in intraepithelial total acid mucin content in chronic calculous cholecystitis. Mucin depletion in mucosal epithelial cells is well known in inflammatory conditions of the gastrointestinal tract. In various forms of colitis presenting with mucus diarrhea or dysentery and showing active inflammation of the mucosa, mucin depletion is a constant finding. Increased mucin secretion by gallbladder mucosa during gallstone formation has been described in literature [6-9, 24]. Earlier investigators have shown that mucins, in addition to being a structural component of gallstones [12], also play an acceleratory role in lithogenesis [25]. Our observation of decreased intraepithelial mucins in inflamed gallbladder mucosa is likely to be a reflection of increased secretion of mucin into bile which is known to occur in calculous disease. The decrease in the intraepithelial mucins in chronic cholecystitis, we found, was due to decrease in sulfomucin which is the predominant type of mucin in gallbladder mucosa. Further, it was observed that cases with severe inflammation showed the maximum decrease in sulfomucin. This was associated with a concomitant increase in sialomucin scores and a high incidence of gastric metaplasia. Intestinal metaplasia on the other hand, did not correlate with the degree of inflammation or sialomucin content. No qualitative changes in gallbladder epithelial mucins have been observed in the earlier studies on chronic cholecystitis [26]. Sialomucins are known to occur in traces in normal gallbladder mucosa and in considerable quantities in metaplastic mucosa. In the present study, an increase in sialomucins was observed in gallbladders showing severe inflammation. Interestingly, it was in this group that gastric metaplasia had the highest incidence (Figure 12). It therefore follows that, sialomucins in significant quantities tend to appear in the areas of gastric metaplasia in the gallbladder mucosa. Their presence is not confined to the goblet cells of intestinal metaplasia which had the lowest percentage of incidence in severe inflammation, in the cases assessed (Figure 13). It has been suggested that antral and intestinal metaplasia in the gallbladder are histogenetically related having the same progenitor cell, and could therefore be parts of a morphological spectrum [27]. Transition from gastric to intestinal metaplasia is a likely possibility [17]. Pre-neoplastic role of intestinal metaplasia in the gallbladder and the metaplasia $\rightarrow$ dysplasia $\rightarrow$ neoplasia sequence have received wide attention among workers $[11,17,28]$. The mucin profile changes with progressive transformation to neoplasia, from normal with sulfomucin predominating through metaplastic and dysplastic showing increasing amounts of sialomucin, to full-fledged neoplastic with sialomucins predominating. The high incidence of gastric metaplasia in severe inflammation and its association with increased expression of sialomucins with the concomitant reduction in sulfomucins would point, perhaps tentatively, towards a role for gastric metaplasia in the proposed chain of events stated above. Basu et al. studied the morphological changes in chronic calculous cholecystitis in relation to the type of stones [29]. They found that inflammation was more severe with pigment 


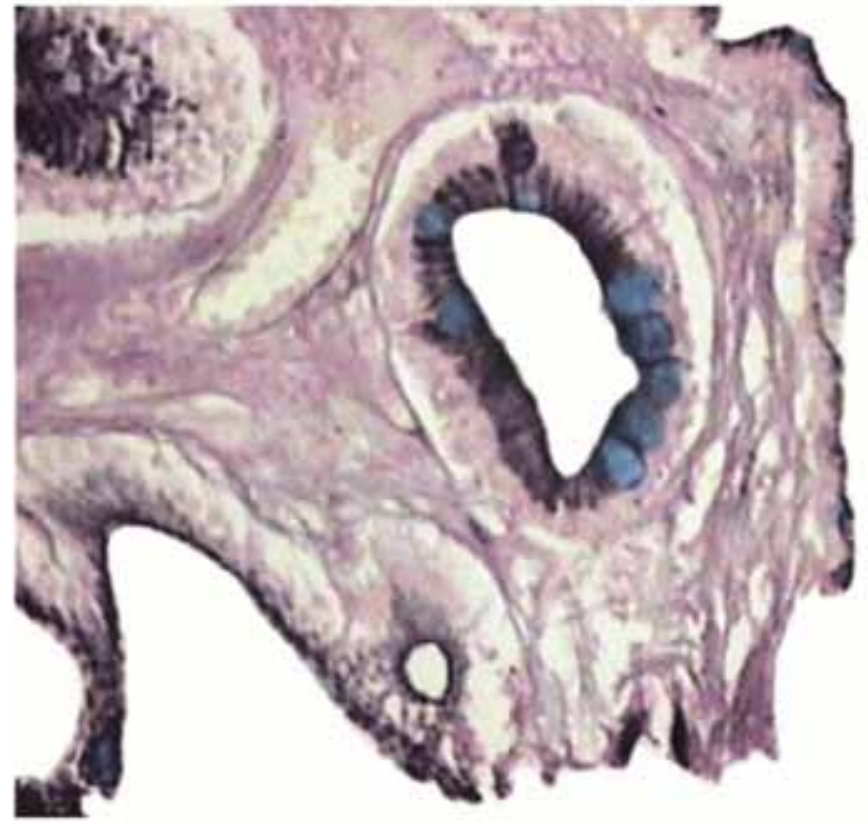

Figure 12: Intestinal Metaplasia-Gallbladder goblet cells contain Alcian blue positive mucin. The columnar cells are HID positive (Brown) (HID-AB stain, x400).

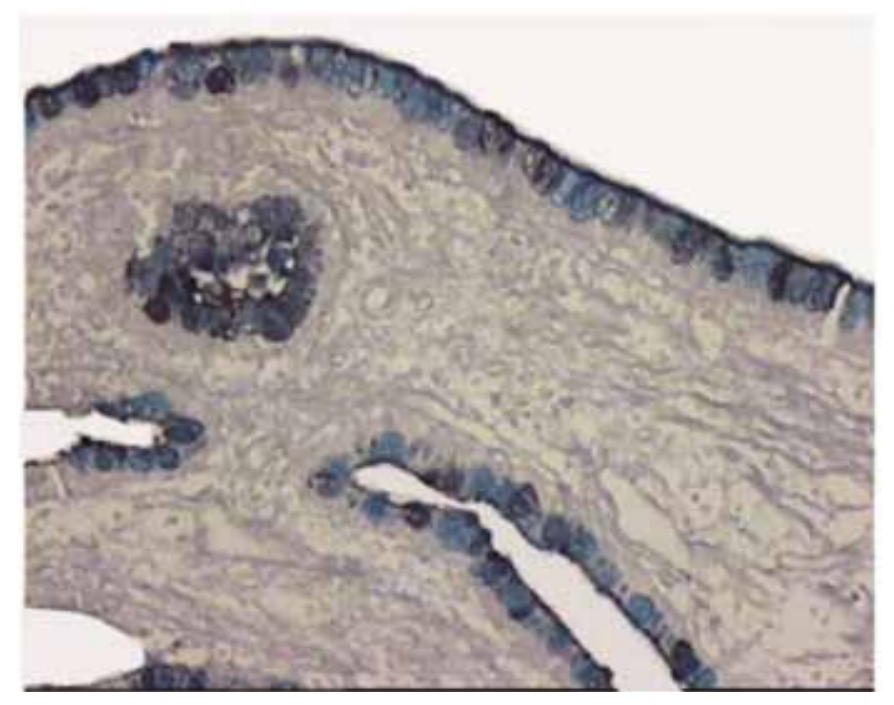

Figure 13: Intestinal Metaplasia-Gallbladder (HID-AB stain, x400).

calculi while fibrosis and related complications were more frequent with cholesterol calculi. The present study supports the association between pigment stones and severe inflammation. Fibrosis also was more in cases with pigment calculi in our study. Mucins have been shown to be a structural component of gallstones $[11,30]$. Histochemical studies carried out on calculi have demonstrated presence of sulfomucins in them, especially in pigment stones [12]. However, no correlation between mucin histochemistry of mucosal epithelium and the type of stone has been recorded in literature. In the present study, pigment stones were found more often in association with severe inflammation, gastric metaplasia and increased expression of sialomucins, as against cholesterol stones. We were unable to establish a statistical significance to the above observations, as the number of cases studied was small, especially in the sialomucin expressing group (even though the scores were high). But the scores and percentage values did show a distinct pattern indicating a correlation between a severe inflammation, gastric metaplasia, sialomucins and pigment calculi (Tables 3-7).

Considering the proposed pathway of Gastric metaplasia $\rightarrow$ Intestinal metaplasia $\rightarrow$ Dysplasia $\rightarrow$ Adenocarcinoma of gallbladder and the proven presence of sialomucins in considerable amounts in dysplastic and neoplastic gallbladder mucosa, it is reasonable to speculate on a pigment stone $\rightarrow$ severe inflammation $\rightarrow$ gastric metaplasia $\rightarrow$ sialomucin link up, with possible transition to dysplasia, with or without the intervention of intestinal metaplasia. Further studies on large series are required to enable us to draw definite conclusions. If such a high risk group emerges, it will be of significance from the preventive, prognostic and therapeutic point of view.

\section{CONCLUSION}

I. The normal gallbladder epithelium contains sulfated acid mucins with traces of neutral and sialomucins.

The sulphomucin content decreases in chronic calculus cholecystitis

II. In chronic calculus cholecystitis with severe (Grade III) inflammation (as against mild inflammation):

1) Total acid mucin content is decreased.

2) This decrease is due to HID positive (sulfo) mucin.

3) Neutral mucin and sialomucin contents are increased.

4) There is a higher incidence of gastric metaplasia and pigment stones.

III. Pigment gallstones tend to have an association with:

1) Severe inflammation

2) Higher degree of fibrosis

3) Gastric metaplasia

4) Presence of sialomucins

More number of cases need to be studied to see whether high risk group consisting of pigment stones $\rightarrow$ severe inflammation $\rightarrow$ gastric metaplasia $\rightarrow$ sialomucin emerges. If it does, will be of therapeutic and prognostic significance.

$$
* * * * * * * * *
$$

\section{Author Contributions}

Ponniah Anupama - Substantial contributions to conception and design, Acquisition of data, Analysis 
and interpretation of data, Drafting the article, Revising it critically for important intellectual content, Final approval of the version to be published

Menon Nirmala V. - Analysis and interpretation of data, Revising it critically for important intellectual content, Final approval of the version to be published

Ramakrishnan Janaky - Analysis and interpretation of data, Revising it critically for important intellectual content, Final approval of the version to be published llias Laila Mohammed - Analysis and interpretation of data, Revising it critically for important intellectual content, Final approval of the version to be published Mohammed Babitha Alingal - Analysis and interpretation of data, Revising it critically for important intellectual content, Final approval of the version to be published Nalakath Asiq Sideeque - Analysis and interpretation of data, Revising it critically for important intellectual content, Final approval of the version to be published

\section{Guarantor}

The corresponding author is the guarantor of submission.

\section{Conflict of Interest}

Authors declare no conflict of interest.

\section{Copyright}

(C) 2014 Ponniah Anupama et al. This article is distributed under the terms of Creative Commons Attribution License which permits unrestricted use, distribution and reproduction in any medium provided the original author(s) and original publisher are properly credited. Please see the copyright policy on the journal website for more information.

\section{REFERENCES}

1. Holzbach RT, Marsh M, Olszewski M, Holan K. Cholesterol solubility in bile. Evidence that supersaturated bile is frequent in healthy man. $\mathrm{J}$ Clin Invest 1973 Jun;52(6):1467-9.

2. Shiffman ML, Moore EW. Bile is supersaturated with calcium in most patients with cholesterol and mixed gallstones (Abstract). Gastroenterology 1987;92:A1775.

3. Neithercut WD. Effect of calcium, magnesium and sodium ions on in vitro nucleation of human gall bladder bile. Gut 1989 May;30(5):665-70.

4. Broomfield P, Chopra R, Sheinbaum R, etal. Formation and prevention of lithogenic bile and gallstones during weight loss (abstract). Gastroenterology 1987;92:1721.

5. LaMont JT, Smith BF, Moore JR. Role of gallbladder mucin in pathophysiology of gallstones. Hepatology 1984 Sep-Oct;4(5 Suppl):51S-6S.

6. Shiffman ML, Sugerman HJ, Kellum HJ, Moore EW. Changes in gallbladder bile composition following gallstone formation and weight reduction. Gastroenterology 1992 Jul;103(1):214-1.

7. Shalin S, Ahlberg J, Einarsson K, Henriksson R,
Danielson A. Quantitative ultrastructural studies of gallbladder epithelium in gallstones free subjects and patients withgall stones. Gut 1990 Jan;31(1):100-5.

8. Madrid JF, Hernandez F, Ballesta J. Characterisation of glycoproteins in the epithelial cells of human and other mammalian gallbladder. A Review. Pathol Int 1996 Apr;46:261-6.

9. Swobodnik W, Wenk H, Janowitz P, et al. Total biliary protein, mucus glycoproteins, cyclic-AMP and apolipoprotein in the gall bladder bile of patients with cholesterol stonesand stone-free controls. Scand J Gastroenterol 1991 Jul;26(7):771-8.

10. Pemsingh RS, MacPherson BR, Scott GW. Mucus hypersecretion in the gallbladder epithelium of the ground squirrel fed a lithogenic diet for the induction of cholesterol gallstones. Hepatology 1987 NovDec;7(6):1267-1.

11. Womack NA, Zeppa R, Irvine GL 3rd. The anatomy of gallstones. Ann Surg 1963 May;157:670-86.

12. Maki T, Matsushiro T, Suzuki N, Nakamura N. Role of sulphated glycoprotein in gallstone formation. Surg Gynecol Obstet 1971 May;132(5):846-54.

13. Malet PF, Locke CL, Trotman BW, Soloway RD. The calcium ionophore A23187 stimulates glycoprotein secretion by the guinea pig gallbladder. Hepatology 1986 Jul-Aug;6(4):569-73.

14. Wahlin T, Thornell E, Jivegard L, Svanvik J. Effects of intraluminal prostaglandins, E2 in vivo on secretory behaviour and ultrastructural changes in mouse gallbladderepithelium. Gastroenterology 1988 Dec;95(6):1632-5.

15. LaMorte WW, LaMont JT, Hale W, Booker ML, Scott TE, Turner B. Gallbladder prostaglandins and lysophospholipids as mediators of mucin secretion during cholelithiasis. Am J Physiol 1986 Nov;251(5 Pt 1):G701-9.

16. Esterly JR, Spicer SS. Mucin histochemistry of human gall bladder: Changes in adenocarcinoma, cystic fibrosis and cholecystitis. J Natl Cancer Inst 1968 Jan;40(1):1-12.

17. Mukhopadhyay S, Landas SK. Putative precursors of gallbladder dysplasia: A review of 400 routinely resected specimens. Arch Pathol Lab Med 2005 Mar;129(3):386-90.

18. Mercer J. Personal communication, In: theory and practice of histological techniques,John D. Bancroft Alan stevens 4th ed 1978:175.

19. Reid L, Clamp JR. The biochemical and histochemical nomenclature of mucus. $\mathrm{Br}$ Med Bull 1978 Jan;34(1):5-8.

20. Kaliner M, Marom Z, Patow C, Shelhamer J. Human respiratory mucus. J Allergy Clin Immunol 1984 Mar;73(3):318-23.

21. Harry C. Cook Carbohydrates In: Theory and practice of histological techniques Jhon D Bancroft, Allan Stevens. 4th ed, Churchill livingstone. NY 1996:176.

22. Varley H In: Practical Clinical Biochemistry. Stones. CBS Publishers, 4th edition 1988:722-3.

23. Laitio M. Morphology and histochemistry of non tumorous gallbladder epithelium. A series of 103 cases. Pathol Res Pract 1980;167(2-4):335-45.

24. Häkkinen I, Laitio M. Epithelial glycoproteins of human gallbladder. Immunological characterization. Arch Pathol 1970 Aug;90(2):137-42.

25. Lee SP. Hypersecretion of mucus glycoproteins by the 
gallbladder epithelium in experimental cholelithiasis. J Pathol 1981 Jul;134(3):199-207.

26. Harvey PR, Rupar CA, Gallinger S, Petrunka $\mathrm{CN}$, Strasberg SM. Quantitative and qualitative comparison of gall bladder mucus glycoprotein from patients with and without gall stones. Gut 1986 Apr;27(4):374-81.

27. Albores-Saavedra J, Nadji M, Henson DE, ZiegelsWeissman J, Mones JM. Intestinal metaplasia of the gallbladder: A morphologic and immunocytochemical study. Hum Pathol 1986 Jun;17(6):614-20.

28. Gupta SC, Misrav, Singh PA, Roy A, Misra SP, Gupta AR. Gallstones and carcinoma gall bladder. Dig Dis
Sci 2000;45:1061-71.

29. Baig SJ, Biswas S, Das S, Basu K, Chattopadhyay G. Histopathological changes in gallbladder mucosa in cholelithiasis: Correlation with chemical composition of gallstones. Trop Gastroenterol 2002 JanMar;23(1):25-7.

30. Smith BF, LaMont JT. Identification of gallbladder mucin-bilirubin complex in human cholesterol gallstone matrix. Effects of reducing agents on in vitro dissolution of matrix and intact gallstones. $\mathrm{J}$ Clin Invest 1985 Aug;76(2):439-5.

\section{ABOUT THE AUTHORS}

Article citation: Anupama P, Menon Nirmala V, Janaky R, Mohammed IL, Alingal MB, Sideeque NA. A histopathological and histochemical study of cholecystitis. Int J Hepatobiliary Pancreat Dis 2014;4:70-80.

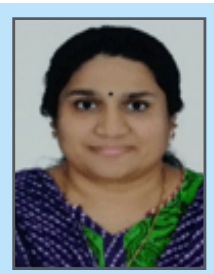

Anupama Ponniah is Assistant professor at department of pathology, MES medical college,KUHS University, Perinthalmanna, Kerala, India. She earned undergraduate degree (MBBS) from Sri Sidhartha Medical College, Bangalore University, Tumkur, India. and postgraduate degree (MD Pathology) from Department of pathology, PSG Institute of Medical Sciences and Research Centre, Coimbatore, India. She has published one research paper and two papers accepted and awaiting for publication in National journal. Her research interests include thyroid lesions, gastric lymphomas, breast cancer. She intends to pursue PhD in future.

Email: anupamasanjaynair@gmail.com

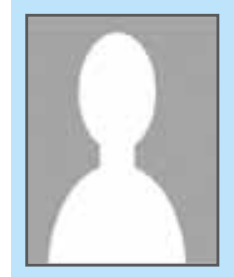

Nirmala V. Menon is Emeritus Professor. She earned undergraduate degree (MBBS) from Trivandrum Medical College, Kerala and postgraduate degree (MD) in Pathology form Christian medical College, Department of Pathology, Vellore, Tamil Nadu, India. She has over 100 publications in national and international journals. Her research interests include gastrointestinal and liver pathology. E-mail:vnmenon2005@yahoo.com

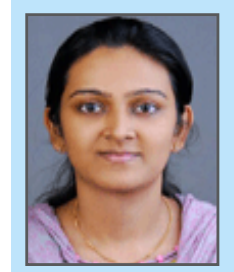

Janaky Ramakrishnan is Junior Resident/Tutor pursuing postgraduation in Pathology in Department of Pathology, MES Medical College, KUHS University, Perinthalmanna, Kerala, India. She earned undergraduate degree (MBBS) from Amrita Institute of Medical Sciences, Amrita Viswa Vidyapeetham, India and is presently pursuing Masters degree (MD) in Pathology in Department of Pathology, MES Medical College, KUHS University, Perinthalmanna, Kerala, India. Her research interests include immunohistochemistry and breast pathology. She intends to pursue Oncopathology in future.

E-mail: janakyram87@gmail.com

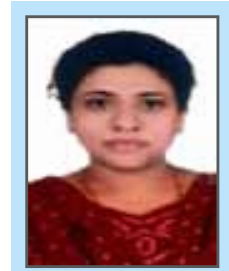

llias Laila Mohammed is Assistant Professor,Department of Pathology, MES Medical College, KUHS University, Perinthalmanna, Kerala, India. She earned undergraduate degree (MBBS) from M.S. RAMIAH Medical College, Bangalore University, Karnataka, India and postgraduate degree (MD) from Department of Pathology, Kasturba Medical College, Mangalore, India. She has an original article awaiting publication and two case reports published in a National journal. Her research interests include cardiac conduction system and thyroid lesions. She intends to pursue $\mathrm{PhD}$ in future.

E-mail: ilias.laila@gmail.com 

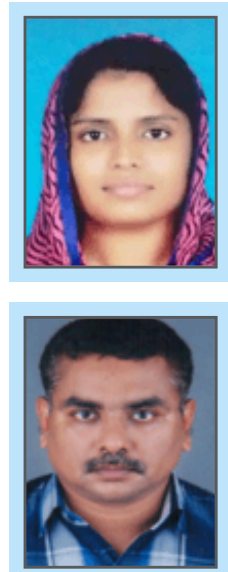

Babitha A. M. is Assistant professor at Department of Pathology, MES Medical college, Perintalmanna, India. She has earned MBBS degree from Academy of Medical Sciences, Pariyaram, Kannur, India and postgraduate degree MD (pathology) from Government Medical College, Kottayam, India. She also earned Diplomate of national board degree in Pathology from Natboard, India. She intends to pursue $\mathrm{PhD}$ and FRCP in future. Her research areas include bone and renal lesions.

E-mail: baiju.faizal@gmail.com

Asiq Nalakath Sideeque is Professor and Head of Department, Department of Pathology, MES Medical College, KUHS University, Perinthalmanna, Kerala, India. He earned undergraduate degree (MBBS) from Kempegowda Institute of Medical Sciences, Bangalore University, Karnataka, India and postgraduate degree form (MD Pathology) from Kasturba Medical College, Mangalore, Manipal Academy of Higher Education, India. He has published papers in National and International journals. His research interests include genetics (Stem cell transplantation)

E-mail: drasiq@gmail.com

Access full text article on other devices

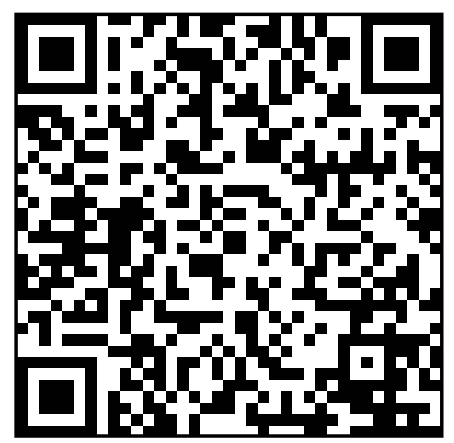

Access PDF of article on other devices

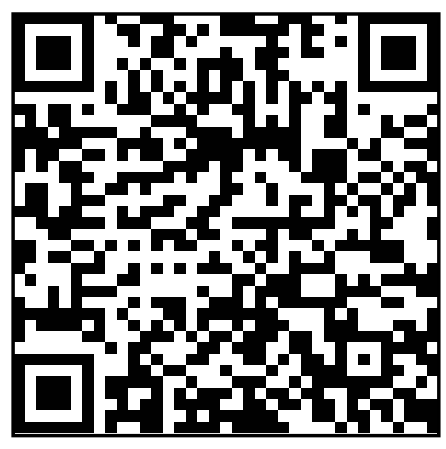

